\title{
PERBEDAAN EFEKTIVITAS MODEL PEMBELAJARAN STUDENT TEAMS ACHIVEMENT DIVISION (STAD) DAN NUMBER HEAD TOGETHER (NHT)
}

\author{
Fathoni Candra Kurniawan \\ Sulastri \\ Universitas Negeri Malang \\ fathonicandrak@yahoo.com
}

\begin{abstract}
This research aims to examine the effectivity of student teams achievement division (STAD) learning model and number head together (NHT) learning model to increase accounting student achievement. Data was gathered by pretest and postest. Data analysis used independent sample t-test. The result show that (1) student achievement using student teams achievement division (STAD) learning model and number head together (NHT) have increased and (2) there are differences between STAD and NHT learning model increasing accounting student achievement.
\end{abstract}

Key words: Student Teams Achivement Division (STAD), Number Head Together (NHT), student achievement

\begin{abstract}
Abstrak: Penelitian ini bertujuan untuk mengetahui efektifitas model pembelajaran STAD dan model pembelajaran NHT dalam meningkatkan hasil belajar akuntansi. Data diperoleh dari pre test, post test. Data dianalisis dengan menggunakan analisis independent sample t-test. Hasil penelitian menunjukkan (1) hasil belajar dengan menggunakan model pembelajaran STAD dan model pembelajaran NHT mengalami peningkatan dan (2) terdapat perbedaan model pembelajaran STAD dengan model pembelajaran NHT dalam meningkatkan hasil belajar Akuntansi.
\end{abstract}

Kata kunci: Student Teams Achivement Division (STAD), Number Head Together (NHT), hasil belajar.

Proses kegiatan belajar mengajar merupakan kegiatan utama di sekolah. Dalam proses ini siswa membangun makna dan pemahaman materi mata pelajaran dengan bimbingan guru. Kegiatan belajar mengajar hendaknya memberikan kesempatan kepada siswa untuk melakukan hal-hal secara aktif dan termotivasi. Guru diharuskan menciptakan suasana belajar yang dapat melibatkan siswa secara aktif.

Untuk menciptakan suasana belajar secara aktif guru harus mempunyai tujuan belajar yang jelas. Berhasilnya suatu tujuan pendidikan tergantung pada bagaimana proses belajar mengajar yang dialami oleh siswa. Seorang guru 
dituntut untuk teliti dalam memilih dan menerapkan metode mengajar yang sesuai dengan tujuan yang ingin dicapai. Sebagaimana menurut AECT (Association Education Center and Technology) "Upaya membelajarkan murid dapat dirancang tidak hanya dalam berinteraksi dengan guru sebagai satu-satunya sumber belajar, melainkan berinteraksi dengan semua sumber belajar yang mungkin dapat dipakai untuk mencapai hasil pembelajaran yang diinginkan" (Majid, 2006:12).

Demi tercapainya tujuan pendidikan di sekolah, guru diberikan kebebasan dalam pengelolaan kelas. Kebebasan dalam mengelola kelas disini adalah dalam hal perencanaan pengajaran yang akan dilakukan oleh guru. William H. Newman yang dikutip oleh Majid (2006: 15) menjelaskan bahwa perencanaan adalah menentukan apa yang akan dilakukan. Perencanaan mengandung rangkaianrangkaian putus yang luas dan penjelasan-penjelasan dari tujuan, penentuan kebijakan, penentuan program, penentuan metode-metode dan prosedur tertentu dan penentuan kegiatan berdasarkan jadwal sehari-hari. Perencanaan ini meliputi strategi, pendekatan, metode, dan model pembelajaran yang efektif, disesuaikan dengan karakteristik mata pelajaran, karakteristik siswa, guru, dan sumber daya yang tersedia di sekolah.

Setiap strategi, pendekatan, metode, dan model pembelajaran yang akan digunakan oleh guru dalam mengajar sangatlah berpengaruh terhadap jalannya proses belajar mengajar. Pemilihan strategi, pendekatan, metode, dan model pembelajaran yang tepat oleh guru akan menentukan hasil belajar siswa baik hasil belajar dari segi kognitif, afektif maupun psikomotor. Dimyati dan Mudjiono (2006: 03) menjelaskan bahwa hasil belajar merupakan hasil dari suatu interaksi tindak belajar yang meliputi ranah kognitif, afektif dan psikomotor. Hasil belajar adalah hasil yang dicapai siswa setelah menempuh pengalaman belajarnya (proses belajar mengajar).

Salah satu faktor yang menentukan pencapaian hasil belajar adalah guru. Guru memegang peranan penting untuk tercapainya hasil belajar yang maksimal. Selain guru, karakteristik mata pelajaran juga mempengaruhi pencapaian hasil belajar. Mata pelajaran yang memiliki karakteristik sulit menuntut guru untuk semakin kreatif dalam mengelola pembelajaran dikelas. Salah satu contoh mata pelajaran yang termasuk dalam kelompok sulit dipelajari di tingkat Sekolah 
Menengah Atas (SMA) adalah Akuntansi. Di dalam mata pelajaran Akuntansi guru berperan penting dalam tercapainya proses belajar mengajar. Ini dikarenakan Akuntansi merupakan pelajaran yang susah untuk dipelajari. Selain itu, akuntansi merupakan salah satu mata pelajaran yang tidak dapat di nalar seperti mata pelajaran lainnya yang dipelajari di jurusan IPS. Dalam pembelajaran Akuntansi materi menghitung lebih banyak daripada materi teori yang dipelajari oleh siswa. Sehingga kehadiran guru dalam proses belajar mengajar sangat diperlukan untuk mendampingi siswa dalam belajar Akuntansi. Indikasi ini dapat memicu prestasi belajar mata pelajaran Akuntansi menjadi rendah. Hal ini tentu menjadi salah satu tugas guru untuk memperbaikinya.

Untuk memacu prestasi belajar siswa, guru dapat menerapkan beberapa model pembelajaran. Model yang dapat digunakan oleh guru sangatlah bermacam-macam baik model pembelajaran kooperatif, quantum learning, problem based learning, dll. Model pembelajaran yang digunakan oleh guru sangatlah berpengaruh terhadap efektivitas dalam pembelajaran, karena model yang digunakan oleh guru berkaitan erat dengan ketercapaian tujuan pembelajaran yaitu kompetensi. Oleh karena itu, pemilihan model yang salah akan mampu membuat efektivitas dari pembelajaran menurun, sehingga perlu adanya perhatian terhadap model yang digunakan guru dalam pembelajarannya.

Pada dasarnya pembelajaran kooperatif dapat meningkatkan kemampuan siswa dalam berpikir kritis, kerjasama antar siswa, dan dapat meningkatkan hasil belajar siswa. Untuk meningkatkan hasil belajar siswa maka peneliti mencoba menerapkan model pembelajaran Student Teams Achivement Division (STAD) dan model pembelajaran Number Head Together (NHT). Pemilihan kedua model pembelajaran tersebut dikarenakan memungkinkan dapat meningkatkan motivasi siswa dalam belajar. Karena kedua model bersifat kooperatif maka siswa dapat belajar bersama sehingga teman yang mampu dan menguasi materi dapat membantu teman-temannya yang belum menguasi materi. Hal ini dikarenakan kemampuan daya tangkap siswa berbeda-beda dan materi mata pelajaran akuntansi sulit untuk dipahami oleh siswa.

Number Head Together (NHT) merupakan suatu model pembelajaran yang dilakukan dengan cara setiap peserta didik diberi nomor, kemudian dibuat 
kelompok. Selanjutnya secara acak guru memanggil nomor peserta didik sebagai ganti pertanyaan langsung kepada seluruh kelas. Pembelajaran ini mengedepankan kepada aktivitas peserta didik dalam mencari, mengolah, dan melaporkan informasi dari beberapa sumber belajar yang akhirnya dipresentasikan di depan kelas. Spencer Kagan dalam Ibrahim (2000: 28) menyatakan bahwa pembelajaran kooperatif tipe Number Head Together (NHT) merupakan salah satu tipe pembelajaran kooperatif yang menekankan pada struktur khusus yang dirancang untuk mengetahui pola interaksi siswa dan memiliki tujuan untuk meningkatkan prestasi belajar dan penguasaan akademik.

Ibrahim (2000) mengemukakan tiga tujuan yang hendak dicapai dalam pembelajaran kooperatif dengan dengan tipe Number Head Together (NHT) yaitu: (1) hasil belajar akademik structural, bertujuan untuk meningkatkan kinerja siswa dalam tugas-tugas akademik; (2) pengakuan adanya keragaman, bertujuan agar siswa dapat menerima teman-temannya yang mempunyai berbagai latar belakang; (3) pengembangan ketrampilan sosial, bertujuan untuk mengembangkan keterampilan sosial siswa antara lain, aktif bertanya, menghargai pendapat orang lain, mau menjelaskan ide atau pendapat, bekerja dalam kelompok dan sebagainya.

Ada beberapa manfaat pada model pembelajaran kooperatif tipe Number Head Together (NHT) terhadap siswa yang hasil belajar rendah yang dikemukakan oleh Lundgren dalam Nardi (2011), yaitu: (1) rasa harga diri menjadi lebih tinggi; (2) memperbaiki kehadiran; (3) penerimaan terhadap individu menjadi lebih besar; (4) perilaku mengganggu menjadi lebih kecil; (5) konflik antara pribadi berkurang; (6) pemahaman yang lebih mendalam; (7) meningkatkan kebaikan budi, kepekaan dan toleransi; (8) hasil belajar lebih tinggi; (9) nilai-nilai kerja sama antar siswa lebih teruji; (10) kreatifitas siswa termotivasi dan wawasan siswa berkembang, karena mereka harus mencai informasi dari berbagai sumber. Sedangkan kekurangan yang terdapat pada model pembelajaran kooperatif tipe Number Head Together (NHT) menurut Nardi (2011), yaitu kelas cenderung jadi ramai, dan jika guru tidak dapat mengkondisikan dengan baik, keramaian itu dapat menjadi tidak terkendali. 
Slavin dalam Khusnul (2013) memaparkan bahwa gagasan utama di belakang STAD adalah memacu siswa agar saling mendorong dan membantu satu sama lain untuk menguasai keterampilan yang di ajarkan guru. Model STAD mempunyai ciri khusus yaitu, setiap siswa mempunyai tanggung jawab supaya setiap anggota kelompok dapat memahami pelajaran dengan saling mengajari dan belajar dari teman-temannya. Jika kita lihat dari proses belajar-mengajar menggunakan model pembelajaran kooperatif tipe STAD ini dapat menunjukkan bahwa pembelajaran kooperatif tipe STAD merupakan tipe pembelajaran kooperatif yang cukup sederhana. Menurut Trianto (2010:73) kegiatan pembelajaran yang dilakukan masih dekat kaitannya dengan pembelajaran konvensional. Hal ini dapat dilihat pada fase-fase pembelajaran kooperatif tipe STAD, yaitu adanya penyajian informasi atau materi pembelajaran. Perbedaan model ini dengan model konvensional terletak pada adanya pemberian penghargaan pada kelompok.

Kelebihan dan kekurangan model pembelajaran kooperatif tipe STAD menurut Roestiyah dalam Khusnul (2013), yaitu: (a) dapat memberikan kesempatan kepada siswa untuk menggunakan keterampilan bertanya dan membahas suatu masalah; (b) dapat memberikan kesempatan kepada siswa untuk lebih intensif mengadakan penyelidikan mengenai suatu masalah; (c) dapat mengembangkan bakat kepemimpinan dan mengajarkan keterampilan berdiskusi; (d) para siswa lebih aktif bergabung dalam pelajaran mereka dan mereka lebih aktif dalam diskusi; (e) dapat memberikan kesempatan kepada siswa untuk mengembangkan rasa menghargai, menghormati pribadi temannya, dan menghargai pendapat orang lain.

Sedangkan kelemahan model pembelajaran kooperatif tipe STAD menurut Dess dalam Khusnul (2013) adalah (a) membutuhkan waktu yang lebih lama untuk siswa sehingga sulit mencapai target kurikulum; (b) membutuhkan waktu yang lebih lama untuk guru sehingga pada umumnya guru tidak mau menggunakan pembelajaran kooperatif; (c) menuntut sifat tertentu dari siswa , misalnya sifat suka bekerja sama.

\section{METODE}


Penelitian ini merupakan penelitian eksperimen. Sugiyono (2011:107) menjelaskan bahwa metode penelitian eksperimen dapat diartikan sebagai metode penelitian yang digunakan untuk mencari pengaruh perlakuan tertentu terhadap yang lain dalam kondisi yang terkendalikan. Desain penelitian eksperimen yang akan digunakan untuk meneliti masalah perbedaan efektivitas hasil belajar mata pelajaran akuntansi siswa yang diajarkan dengan model pembelajaran Student Teams Achivement Division (STAD) dengan hasil belajar siswa yang diajarkan dengan model pembelajaran Number Head Together (NHT) adalah Randomized Pretest-Posttest Control Group Design. Randomized Pretest-Posttest Control Group Design merupakan desain penelitian eksperimental yang didasarkan pada hasil pretest dan postest kepada kelas model pembelajaran Student Teams Achivement Division (STAD) dan kelas model pembelajaran Number Head Together (NHT).

Penelitian ini dilakukan pada SMA negeri 6 Malang. Populasi dalam penelitian ini adalah seluruh siswa SMA Negeri 6 Malang tahun pelajaran 2012/2013 kelas XI IPS yang terbagi dalam 4 kelas yaitu kelas XI IPS 1, XI IPS 2, XI IPS 3, dan XI IPS 4, sedangkan sampel dari penelitian adalah 2 kelas/kelompok yang dipilih secara acak. Kelas yang pertama (kelas XI IPS 1) dijadikan sebagai kelas eksperimen 1 yaitu kelas yang diberikan perlakuan pembelajaran dengan menggunakan model pembelajaran Student Teams Achivement Division (STAD), sedangkan kelas kedua (kelas XI IPS 2) dijadikan sebagai kelas eksperimen 2 yang diberi perlakuan pembelajaran dengan menggunakan model pembelajaran Number Head Together (NHT).

Instrumen yang digunakan dalam penelitian ini adalah instrumen penelitian yang meliputi RPP, butir soal, dan lembar kerja siswa (LKS). Selanjutnya instrumen pengukuran yang meliputi tes yang berjumlah 30 soal yang diberikan saat pre test dan post test. Sebelum diujikan pada siswa soal tersebut di uji tingkat validitas, reliabilitas, tingkat kesukaran dan daya beda. Uji tingkat validitas butir soal dengan menggunakan program SPSS versi 16,0 For Windows dengan rumus korelasi product moment. Analisis reliabilitas dengan menggunakan rumus K-R. 21 yang diketemukan oleh Kuder dan Richardson menurut (Arikunto, 2012:232). Analisis tingkat kesukaran dilakukan untuk 
mengetahui sukar dan mudahnya suatu soal. Analisis tingkat kesukaran tes subjektif dengan menggunakan rumus P (Arikunto, 2012:223). Uji daya beda item tes subjektif dilakukan dengan menggunakan rumus indeks diskriminasi (Arikunto, 2012:228).

Data yang diuji dalam penelitian ini adalah nilai hasil belajar (gain score). Uji hipotesis menggunakan uji $\mathrm{t}$ independen (independent $t$-test). Sebelum uji hipotesis dilakukan terlebih dahulu uji normalitas dan uji homogenitas. Uji normalitas pada penelitian ini menggunakan rumus Kolmogorov Smirnov Test. Uji homogenitas menggunakan Levene's tes for equality of variences.

\section{HASIL DAN PEMBAHASAN}

\section{Hasil}

Berikut disajikan hasil distribusi frekuensi pretest untuk kelas eksperimen 1 dan kelas eksperimen 2 pada tabel 1 .

Tabel 1. Distribusi Frekuensi Data Kemampuan Awal (Pre Test) Kelas Eksperimen 1 dan Kelas Eksperimen 2

\begin{tabular}{lllllll}
\hline \multicolumn{2}{l}{ Kelas Eksperimen 1 } & \multicolumn{3}{l}{ Kelas Eksperimen 2 } & Kriteria \\
\cline { 1 - 5 } Interval & $\mathbf{F}$ & $\begin{array}{l}\text { Persentase } \\
(\boldsymbol{\%})\end{array}$ & Interval & $\mathbf{f}$ & $\begin{array}{l}\text { Persentase } \\
(\boldsymbol{\%})\end{array}$ & \\
\hline $85-100$ & 0 & 0 & $85-100$ & 0 & 0 & Sangat baik \\
$70-84$ & 2 & 6,25 & $70-84$ & 3 & 9,09 & Baik \\
$55-69$ & 14 & 43,75 & $55-69$ & 16 & 48,49 & Cukup \\
$40-54$ & 13 & 40,62 & $40-54$ & 8 & 24,24 & Kurang \\
$<39$ & 3 & 9,38 & $<39$ & 6 & 18,18 & Kurang \\
& & & & & & \\
\hline
\end{tabular}

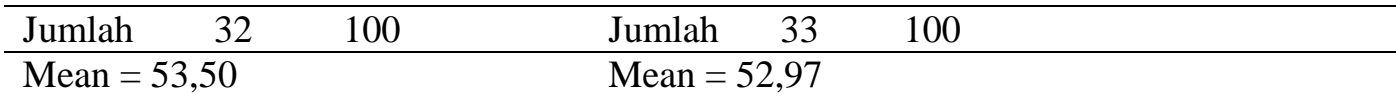

Berdasarkan tabel di atas dapat diketahui bahwa skor kemampuan awal pada kelas eksperimen 1 yang berjumlah 32 siswa sebagian besar siswa mendapat skor dengan kriteria cukup yaitu 14 siswa atau 43,75\%. Siswa yang memiliki kemampuan awal dengan kriteria baik yaitu 2 siswa atau sebesar 6,25 \%, yang mempunyai kriteria kurang sebanyak 13 siswa atau 40,62\% dan yang mempunyai kriteria kurang sekali sebanyak 3 siswa atau 9,38\%. Sedangkan skor kemampuan awal pada kelas eksperimen 2 yang berjumlah 33 sebagian besar siswa juga mendapat skor dengan kriteria cukup yaitu sebanyak 16 siswa atau 48,49\%. Siswa yang memiliki kemampuan awal dengan kriteria baik yaitu 3 siswa atau 9,09\%, 
yang mempunyai kriteria kurang sebanyak 8 siswa atau $24,24 \%$ dan yang mempunyai kriteria kurang sekali sebanyak 6 siswa atau 18,18\%. Pada kemampuan awal ini, baik pada kelas eksperimen 1 maupun kelas eksperimen 2 tidak ada siswa yang mendapat skor dengan kriteria baik sekali.

Berdasarkan Tabel 1 juga dapat diketahui bahwa kemampuan awal antara kelas eksperimen 1 dan kelas eksperimen 2 relatif sama. Hal tersebut dapat dilihat dari rata-rata nilai pre test yang diperoleh, yaitu rata-rata kelas eksperimen 1 sebesar 53,50, sedangkan kelas eksperimen 2 memiliki rata-rata sebesar 52,97. Selisih skor rata-rata pre test antara kelas eksperimen 1 dan eksperimen 2 hanya 0,53. Selain itu didukung juga oleh hasil uji beda rata-rata kemampuan awal siswa yang menunjukkan nilai sig $=0,872>0,05$, yang artinya tidak ada perbedaan yang signifikan antara kemampuan awal kelas eksperimen 1 dan kelas eksperimen 2. Hal tersebut berarti bahwa seluruh subjek yang diambil sudah memiliki kemampuan awal yang relatif sama.

Tabel 2. Distribusi Frekuensi Data Kemampuan Akhir (Post Test) Kelas Eksperimen 1 dan Kelas Eksperimen 2

\begin{tabular}{|c|c|c|c|c|c|c|}
\hline \multicolumn{3}{|c|}{ Kelas Eksperimen 1} & \multicolumn{3}{|c|}{ Kelas Eksperimen 2} & \multirow[b]{2}{*}{ Kriteria } \\
\hline Interval & $\mathbf{F}$ & $\begin{array}{l}\text { Persentase } \\
(\%)\end{array}$ & Interval & f & $\begin{array}{l}\text { Persentase } \\
(\%)\end{array}$ & \\
\hline $85-100$ & 6 & 18,75 & $85-100$ & 3 & 9,09 & Sangat baik \\
\hline $70-84$ & 21 & 65,63 & $70-84$ & 17 & 51,52 & Baik \\
\hline $55-69$ & 4 & 12,5 & $55-69$ & 10 & 30,3 & Cukup \\
\hline $40-54$ & 1 & 3,12 & $40-54$ & 3 & 9,09 & Kurang \\
\hline$<39$ & 0 & 0 & $<39$ & 0 & 0 & $\begin{array}{l}\text { Kurang } \\
\text { sekali }\end{array}$ \\
\hline Jumlah & 32 & 100 & Jumlah & 33 & 100 & \\
\hline \multicolumn{3}{|c|}{ Mean $=76,77$} & \multicolumn{3}{|c|}{ Mean $=71,62$} & \\
\hline
\end{tabular}

Berdasarkan tabel di atas dapat diketahui bahwa skor kemampuan akhir pada kelas eksperimen 1 yang berjumlah 32 siswa sebagian besar siswa mendapat skor dengan kriteria baik yaitu 21 siswa atau 65,63\%. Siswa yang memiliki kemampuan akhir sangat baik yaitu 6 siswa atau sebesar 18,75\%, yang mempunyai kriteria cukup sebanyak 4 siswa atau 12,5\% dan yang mempunyai kriteria kurang sebanyak 1 siswa atau 3,12\%. Sedangkan skor kemampuan awal pada kelas eksperimen 2 yang berjumlah 33 sebagian besar siswa juga mendapat skor dengan kriteria baik yaitu sebanyak 17 siswa atau 51,52\%. Siswa yang 
memiliki kemampuan awal dengan kriteria sangat baik yaitu 3 siswa atau 9,09\%, yang mempunyai kriteria cukup sebanyak 10 siswa atau 30,3\% dan yang mempunyai kriteria kurang sebanyak 3 siswa atau 9,09\%. Pada skor kemampuan akhir ini, baik pada kelas eksperimen 1 maupun kelas eksperimen 2 tidak ada siswa yang mendapat skor dengan kriteria kurang sekali.

Berdasarkan Tabel 2 juga dapat diketahui bahwa kemampuan akhir antara kelas eksperimen 1 dan kelas eksperimen 2 mengalami perbedaan. Hal tersebut dapat dilihat dari rata-rata skor post test yang diperoleh, yaitu rata-rata kelas eksperimen 1 sebesar 76,77, sedangkan kelas eksperimen 2 memiliki rata-rata sebesar 71,62. Selisih skor rata-rata post test antara kelas eksperimen 1 dan eksperimen 2 cukup besar, yaitu sebesar 5,15. Hal tersebut menunjukkan bahwa rata-rata kemampuan akhir kelas eksperimen 1 lebih tinggi daripada kelas eksperimen 2.

Data yang dianalisis pada penelitian ini untuk mengetahui efektifitas model pembelajaran STAD dengan model pembelajaran NHT dalam meningkatkan hasil belajar akuntansi adalah hasil belajar (gain score). Ringkasan hasil belajar (gain score) hasil belajar dapat dilihat pada Tabel 3.

Tabel 3. Distribusi Frekuensi Data Hasil Belajar Siswa (Gain Score) Kelas Eksperimen 1 dan Kelas Eksperimen 2

\begin{tabular}{llllll}
\hline \multicolumn{2}{l}{ Kelas Eksperimen 1 } & \multicolumn{3}{l}{ Kelas Eksperimen 2 } \\
\hline Interval & $\mathbf{F}$ & $\begin{array}{l}\text { Persentase } \\
(\boldsymbol{\%})\end{array}$ & Interval & $\mathbf{F}$ & Persentase (\%) \\
& & 3,12 & $39-44$ & 0 & 0 \\
$39-44$ & 1 & 3,12 & $33-38$ & 0 & 0 \\
$33-38$ & 1 & $25-32$ & 4 & 12,12 \\
$27-32$ & 8 & 25 & $21-26$ & 6 & 18,18 \\
$21-26$ & 7 & 21,88 & $15-20$ & 15 & 45,45 \\
$15-20$ & 12 & 37,5 & $9-14$ & 5 & 15,15 \\
$9-14$ & 3 & 9,38 & $3-8$ & 3 & 9,09 \\
$3-8$ & 0 & 0 & Jumlah & 33 & 100 \\
\hline Jumlah & 32 & 100 & \multicolumn{5}{l}{ Mean = 17,97 } \\
\hline \multicolumn{7}{l}{ Mean = 22,62 } \\
\hline
\end{tabular}

Tabel 3 menunjukkan bahwa gain score hasil belajar pada kelas eksperimen 1 sebagian besar berada pada interval 15-20, yaitu sebesar 37,5\%, dan memiliki rata-rata gain score 22,62. Sedangkan pada kelas eksperimen 2 gain score hasil belajar sebagian besar juga berada pada interval 15-20 yaitu sebesar 45,45\%. Kelas eskperimen 2 memiliki rata-rata gain score 17,97. Hal tersebut 
menunjukkan bahwa rata-rata hasil belajar kelas eksperimen 1 lebih tinggi daripada kelas eksperimen 2.

Sebelum dilakukan uji hipotesis maka data diuji normalitas dan homogenitas terlebih dahulu. Hasil uji normalitas menunjukkan hasil belajar (gain score) akuntansi kelompok eksperimen 1 dan eksperimen 2 masing-masing sebesar 0,353 dan 0,140 yang mana lebih besar dari 0,05, artinya data terdistribusi normal. Ringkasan hasil uji normalitas dapat dilihat pada Tabel 4. Hal yang sama ditunjukkan hasil uji homogenitas hasil belajar (gain score) akuntansi sebesar 0,723 yang mana lebih besar dari 0,05 sehingga data memiliki variasi yang sama (homogen). Ringkasan hasil uji homogenitas dapat dilihat pada Tabel 5.

Tabel 4. Hasil Uji Normalitas

\begin{tabular}{llll}
\hline Kelompok & Signifikasi (asymp.sig) & $\begin{array}{l}\text { Alpha } \\
\mathbf{5 \%}\end{array}$ & Kondisi \\
\hline $\begin{array}{l}\text { eksperimen } \\
1\end{array}$ & 0,353 & 0,05 & Sig > Alpha \\
$\begin{array}{l}\text { eksperimen } \\
2\end{array}$ & 0,140 & 0,05 & Sig > Alpha \\
\hline
\end{tabular}

Tabel 5. Hasil Uji Homogenitas

\begin{tabular}{ccccl}
\hline Kelompok & Levene Test & (asymp.sig) & Alpha 5\% & Kondisi \\
\hline Gain Score & 0,127 & 0,723 & 0,05 & Sig > Alpha \\
\hline
\end{tabular}

Hasil uji hipotesis menggunakan uji t independen (independent t-test) menunjukkan nilai signifikansi perbedaan model pembelajaran STAD dengan model pembelajaran NHT adalah 0,005 yang lebih kecil dari 0,05. Hal ini berarti terdapat perbedaan model pembelajaran STAD dengan model pembelajaran NHT. Ringkasan hasil uji t independen (independent t-test) dapat dilihat pada Tabel 6.

Tabel 6. Hasil Uji Hipotesis

\begin{tabular}{ccccc}
\hline Kelompok & Mean & Sig. & Alpha 5\% & Kondisi \\
\hline eksperimen1 & 22,62 & \multirow{2}{*}{0,005} & 0,05 & Sig < alpha \\
\hline eksperimen2 & 17,97 & & & \\
\hline
\end{tabular}

\section{PEMBAHASAN}

\section{Hasil Belajar Dengan Model Pembelajaran Student Teams Achivement Division (STAD)}

Model pembelajaran Student Teams Achivement Division (STAD) merupakan salah satu model pembelajaran kooperatif yang efektif dalam 
meningkatkan hasil belajar siswa. Hal ini dipengaruhi adanya tahap kerja kelompok yang dapat meningkatkan pengetahuan siswa. Dalam kegiatan kerja kelompok tersebut siswa saling membantu dalam memecahkan masalah. Hal ini sesuai dengan apa yang dikemukakan oleh Slavin (dalam Rusman, 2012: 214) bahwa"gagasan utama di belakang STAD adalah memacu siswa agar saling mendorong dan membantu satu sama lain untuk menguasai keterampilan yang diajarkan guru". Sehingga jika siswa menginginkan kelompok memperoleh hadiah, mereka harus membantu teman sekelompok mereka dalam mempelajari pelajaran.

Tahap kerja kelompok yang diterapkan di atas sesuai dengan tahapantahapan yang dikemukakan oleh Isjoni (2011: 51) yaitu belajar kooperatif tipe STAD melalui lima tahapan yang meliputi (i) tahap penyajian materi, (ii) tahap kegiatan kelompok, (iii) tahap tes individual, (iv) tahap penghitungan skor pengembangan individu, (v) tahap pemberian penghargaan kelompok.

Berdasarkan Tabel 1 dan Tabel 2 hasil belajar yang diperoleh oleh siswa yang sudah diberi perlakuan model pembelajaran Student Teams Achivement Division (STAD) mengalami peningkatan. Peningkatan hasil belajar siswa diukur dengan menggunakan tes berupa multiple choice yang diberikan kepada siswa. Tes yang diberikan kepada siswa dilakukan selama 2 kali yaitu pretest dan posttest. Hasil rata-rata dari pretest sebesar 53,50 dan hasil rata-rata dari posttest sebesar 76,77. Jika dibandingkan dari nilai rata-rata pretest dan posttest terdapat peningkatan sebesar $22,61 \%$. Selain itu, kondisi kelas yang diberi perlakuan

model pembelajaran Student Teams Achivement Division (STAD) lebih aktif dalam memberikan pendapat dalam menjawab pertanyaan. Dalam proses diskusi siswa saling membantu, siswa yang lebih pandai bisa membantu teman yang kurang pandai.

\section{Hasil Belajar Dengan Model Pembelajaran Number Head Together (NHT)}

Model pembelajaran Number Head Together (NHT) merupakan salah satu model pembelajaran kooperatif yang menekankan pada pola interaksi siswa dan bertujuan untuk meningkatkan hasil belajar siswa. Interaksi ini dipengaruhi adanya tahap berpikir bersama yang dapat meningkatkan pemahaman siswa. 
Dalam tahap berpikir bersama tersebut siswa bahu membahu dalam mencari jawaban dari permasalahan yang diajukan. Hal ini sesuai dengan apa yang dikemukakan oleh Nurhadi dan Senduk (2004: 67) bahwa model pembelajaran Number Head Together (NHT) ini melibatkan siswa dalam mereview bahan yang tercakup dalam suatu pelajaran yang mengecek dan memeriksa pemahaman mereka mengenai isi pelajaran tersebut.

Tahap berpikir bersama yang diterapkan di atas sesuai dengan tahapantahapan yang dikemukakan oleh Nurhadi dan Senduk (2004: 67) menyatakan 4 langkah sebagai berikut (i) penomoran (Numbering), (ii) pengajuan pertanyaan (Questioning), (iii) berpikir bersama (Heads together), (iv) pemberian jawaban (Answering).

Berdasarkan Tabel 1 dan Tabel 2 hasil belajar yang diperoleh oleh siswa yang sudah diberi perlakuan model pembelajaran Number Head Together (NHT) mengalami peningkatan. Peningkatan hasil belajar siswa diukur dengan menggunakan tes berupa multiple choice yang diberikan kepada siswa. Tes yang diberikan kepada siswa dilakukan selama 2 kali yaitu pretest dan posttest. Hasil rata-rata dari pretest sebesar 52,97 dan hasil rata-rata dari posttest sebesar 71,62. Jika dibandingkan dari nilai rata-rata pretest dan posttest terdapat peningkatan sebesar $18,65 \%$.

\section{Perbedaan Efektivitas Model Pembelajaran Student Teams Achivement Division (STAD) dan Number Head Together (NHT)}

Belajar mengajar sebagai suatu proses yang mengandung tiga unsur yang dapat dibedakan, yaitu tujuan pengajaran (instruksional), pengalaman (proses) belajar-mengajar, dan hasil belajar (Sudjana, 2010: 02). Dalam suatu proses pembelajaran akan menghasilkan hasil belajar. Winkel dalam Muzakki (2013) menyatakan bahwa terdapat dua faktor yang menyebabkan adanya perbedaan hasil belajar yakni faktor internal dan faktor eksternal. Faktor internal meliputi kecerdasan, motivasi, minat, perasaan, dan kondisi fisik. Sedangkan faktor eksternal meliputi lingkungan sosial, keluarga, guru, dan proses pembelajaran yang ada di sekolah. Penerapan model pembelajaran Student Teams Achievement 
Divisions dan Number heads Together adalah salah satu contoh faktor eksternal yang dapat mempengaruhi hasil belajar.

Hasil penelitian menunjukkan bahwa terdapat perbedaan Model pembelajaran Student Teams Achivement Division (STAD) dengan model pembelajaran Number Head Together (NHT). Selain itu, hasil penelitian ini menunjukkan bahwa model pembelajaran Student Teams Achivement Division (STAD) lebih efektif dengan hasil belajar siswa yang diajarkan dengan model pembelajaran Number Head Together (NHT). Hal ini berdasarkan dari hasil belajar siswa yang diperoleh siswa pada proses pembelajarannya menggunakan model pembelajaran Student Teams Achivement Division (STAD) memiliki ratarata lebih tinggi 4,65\% dibanding hasil belajar siswa yang mendapatkan pembelajaran menggunakan model pembelajaran Number Head Together (NHT).

Disamping itu dalam model pembelajaran Student Teams Achivement Division (STAD) dapat meningkatkan pemahaman materi karena siswa diberi waktu untuk saling membantu sama lain sedangkan pada model pembelajaran Number Head Together (NHT) peningkatan pemahaman siswa pada saat pemecahan masalah. Peningkatan pemahaman materi ini ditunjukkan dari hasil rata-rata siswa yang meningkat dari hasil rata-rata pretest 53,50 dan hasil rata-rata posttest sebesar 76,77. Selain meningkatkan pemahaman materi model pembelajaran Student Teams Achivement Division (STAD) dapat menciptakan suasana belajar yang menyenangkan dan menambah rasa perhatian siswa sehingga dapat mengurangi tingkat kebosanan dan kejenuhan siswa pada saat kegiatan pembelajaran, karena siswa dapat saling berinteraksi antar sesama dan tidak merasa terbebani oleh tugas individu, sehingga dapat mencairkan suasana menjadi lebih santai sedangkan pada model pembelajaran Number Head Together (NHT) pada pemecahan masalah tertuju pada setiap individu sehingga siswa merasa terbebani oleh tanggung jawab oleh masalah yang dihadapi. Selain itu, model pembelajaran Student Teams Achivement Division (STAD) memberikan hadiah atau penghargaan yang akan memberikan dorongan bagi siswa untuk mencapai hasil yang lebih tinggi, sehingga siswa termotivasi untuk mendapatkan hadiah atau penghargaan yang diberikan oleh guru sedangkan pada model pembelajaran Number Head Together (NHT) tidak terdapat pemberian hadiah sehingga siswa 
tidak memiliki motivasi seperti yang terjadi pada model pembelajaran Student Teams Achivement Division (STAD).

Disamping terdapat keunggulan, model pembelajaran Student Teams Achivement Division (STAD) dan model pembelajaran Number Head Together (NHT) terdapat kelemahan yaitu membutuhkan waktu yang relatif lama. Pada model pembelajaran Student Teams Achivement Division (STAD) ini dikarenakan langkah-langkah yang dilaksanakan lebih banyak dan terdapat langkah tes individu/kuis yang membuat model pembelajaran Student Teams Achivement Division (STAD) membutuhkan waktu yang relatif lama. Sedangkan pada model pembelajaran Number Head Together (NHT) sering terjadi keramaian sehingga waktu banyak terbuang dan membuat waktu relatif lama.

Berdasarkan penjelasan tersebut dapat diketahui bahwa model pembelajaran Student Teams Achivement Division (STAD) mempunyai pengaruh terhadap peningkatan hasil belajar Akuntansi secara signifikan dibandingkan dengan model pembelajaran Number Head Together (NHT). Hal ini disebabkan karena model pembelajaran Student Teams Achivement Division (STAD) saling menguatkan untuk meningkatkan kemampuan kognitif yang dimiliki oleh siswa melalui proses berpikir bersama dan mengeluarkan pendapat secara individu.

Dalam pelaksanaannya, model pembelajaran Student Teams Achivement Division (STAD) memiliki beberapa keunggulan dan kelemahannya. Adapun keunggulan model tersebut adalah sebagai berikut (i) meningkatkan pemahaman materi karena siswa diberi waktu untuk saling membantu sama lain, (ii) menciptakan suasana belajar yang menyenangkan dan menambah rasa perhatian siswa sehingga dapat mengurangi tingkat kebosanan dan kejenuhan siswa pada saat kegiatan pembelajaran, (iii) hadiah atau penghargaan yang diberikan akan memberikan dorongan bagi siswa untuk mencapai hasil yang lebih tinggi. Keunggulan ini sesuai dengan yang dijelaskan oleh Roestiyah (dalam Khusnul, 2013). Beberapa kelebihan model pembelajaran Student Teams Achivement Division (STAD) adalah (i) dapat memberikan kesempatan kepada siswa untuk menggunakan keterampilan bertanya dan membahas suatu masalah, (ii) dapat memberikan kesempatan kepada siswa untuk mengembangkan rasa menghargai, menghormati pribadi temannya, dan menghargai pendapat orang lain. 
Di dalam pelaksanaanya, model pembelajaran Student Teams Achivement Division (STAD) juga mempunyai beberapa kelemahan antara lain (i) membutuhkan waktu yang relatif lama sehingga guru harus memperhatikan alokasi waktu yang tersedia agar langkah-langkah pembelajaran dapat terlaksana dengan baik terutama saat tes individual/kuis, (ii) menuntut sifat tertentu dari siswa , misalnya sifat suka bekerja sama. Kelemahan ini sesuai dengan dijelaskan oleh Dess (dalam Khusnul, 2013).

\section{SIMPULAN}

Berdasarkan hasil dan pembahasan dapat disimpulkan bahwa hasil belajar dengan menggunakan model pembelajaran Student Teams Achivement Division (STAD) dan model pembelajaran Number Head Together (NHT) mengalami peningkatan. Selanjutnya, Terdapat perbedaan Model pembelajaran Student Teams Achivement Division (STAD) dengan model pembelajaran Number Head Together (NHT). Selain itu, model pembelajaran Student Teams Achivement Division (STAD) lebih efektif dibandingkan dengan model pembelajaran Number Head Together (NHT) dalam hasil belajar kelas XI IPS SMAN 6 Malang. Hal ini dapat dilihat dari hasil belajar siswa yang diperoleh siswa pada proses pembelajarannya menggunakan model pembelajaran Student Teams Achivement Division (STAD) memiliki rata-rata lebih tinggi 4,65 \% dibanding hasil belajar siswa yang mendapatkan pembelajaran menggunakan model pembelajaran Number Head Together (NHT).

Saran untuk penelitian selanjutnya adalah penelitian lanjutan diharapkan dapat melengkapi dan memperbaiki penelitian yang pernah dilakukan sebelumnya, yaitu penelitian disarankan dilakukan di sekolah yang siswanya benar-benar memiliki kemampuan akademik rendah, sehingga hasil penelitan terlihat secara jelas perubahan yang terjadi sebelum diberi perlakuan dan sesudah perlakuan.

\section{DAFTAR RUJUKAN}


Arikunto, Suharsimi. 2012. Dasar-Dasar Evaluasi Pendidikan Edisi 2. Jakarta: Bumi Aksara.

Dimyati dan Mudjiono. 2006. Belajar Dan Pembelajaran. Jakarta: PT Rineka Cipta.

Ibrahim. 2000. Teori Pembelajaran. Jakarta: Angkasa.

Isjoni. 2011. Cooperative Learning: Mengembangkan Kemampuan Belajar Berkelompok. Bandung: Alfabeta.

Khusnul, T. dkk. 2013. Model Pembelajaran Kooperatif Tipe Student Teams Achievement Division (STAD), (online), (http://desykartikaputri.wordpress.com/2013/01/02/makalah-modelpembelajaran-stad-student-teams-achievement-division/), diakses tanggal 24 Februari 2013.

Majid, Abdul .2006. Perencanaan Pembelajaran. Bandung: PT Remaja Rosdakarya.

Muzakki, M. H. 2013. Pengaruh Penerapan Model Pembelajaran Kooperatif Think Pair Share Dipadu Dengan Peta Pikiran (Mind Map) Terhadap Motivasi Dan Hasil Belajar Geografi Siswa Kelas X SMA Negeri 4 Malang. Skripsi tidak diterbitkan. Malang: Universitas Negeri Malang.

Nardi. 2011. Pembelajaran Numbered Head Together (NHT), (online), (http://nardishome.blogspot.com/2011/04/pembelajaran-numbered-headtogether-nht.html), diakses tanggal 24 Februari 2013.

Nurhadi dan Senduk. 2004. Pembelajaran Konstektual dan Penerapannya dalam $K B K$. Malang: UM Press.

Rusman. 2012. Model-model Pembelajaran: Mengembangkan Profesionalisme Guru (Edisi Kedua). Jakarta: PT RajaGrafindo Persada.

Sudjana, Nana. 2010. Penilaian Hasil Proses Belajar Mengajar. Bandung: PT Remaja Rosdakarya.

Sugiyono. 2011. Metode Penelitian Pendidikan (Pendekatan Kuantitatif, Kualitatif, dan $R \& D)$. Bandung: Alfabeta.

Trianto (2010). Mendesain Model Pembelajaran Inovatif-Progresif: Konsep Landasan, dan Implementasinya pada Kurikulum Tingkat Satuan Pendidikan (KTSP). Jakarta: Kencana. 